\title{
小角および超小角X線散乱法によるコロイド系 および高分子ゲルの構造評価
}

高分子の局所形態などナノメートルオーダーでの構造評 価には, 小角 X 線散乱 (SAXS) 法が有力な手段として用い られてきた。一方, SAXS 法で解析可能な領域を超える, $10 \mathrm{~nm} \sim 1 \mu \mathrm{m}$ オーダーにわたる高分子の組織化あるいは 集積構造への関心が近年高まっており，それらの構造評価 に有効な超小角 X 線散乱 (USAXS) 法が 1990 年頃より利 用されるようになってきた1)。本稿ではこれら X 線散乱法 の最近の適用例について筆者らの研究を中心に紹介する。

まず，静電的相互作用による構造形成に関する最む基本 的な系である，球状荷電粒子分散系の構造評価について触 れる。粒子径分布の狭い荷電コロイド粒子は, 脱塩した水 分散液中で結晶構造を形成する。結晶格子構造および格子 定数 (a) の決定は, 荷電粒子間の相互作用を解明するうえ で重要である。この場合, 構造が分散液中で形成されるた め電子顕微鏡法の適用は難しく, また光散乱法も多重散乱 の影響などにより解析が困難となるが，X 線法ではそのよ うな問題は生じにくい。構造がマイクロメートルオーダー 近くに達するため, 精密な構造評価にはUSAXS 法が必要 となる。Si 単結晶を用いて平行な X 線を得る Bonse-Hart 型 USAXS 装置では; $0.001^{\circ}$ の小角分解能が得られ, $8 \mu \mathrm{m}$ に及ぶ構造の決定が理論的に可能となる。X 線を鉛直面に 対してのみ平行にする一次元 (1D-)USAXS ${ }^{1)}$ は無配向試料 に対して有用であるが，さらに水平面に対してあX線を 平行にする二次元 (2D-)USAXS では, 配向試料にも適用 でき, 試料軸回転機構により散乱べクトルの大きさ $q[=(4 \pi / \lambda) \sin \theta, \lambda: \mathrm{X}$ 線の波長, $2 \theta:$ 散乱角 $]$ が $10^{-3} \sim$ $10^{-2} \mathrm{~nm}^{-1}$ オーダーの超小角領域で散乱強度を任意の散 乱ベクトル q に対して測定できる。筆者らは 2D-USAXS 装置2)を用いて, 直径 $112 \mathrm{~nm}$ のシリカコロイド系から 20 個以上の回折ピークを観測し，ピークにおける q から, 結 晶格子構造およびその配向を決定した。 $a$ の実測值から求 まる最近接粒子間距離 $(280 \mathrm{~nm})$ は, 粒子濃度加ら計算さ れる平均粒子間距離 $(307 \mathrm{~nm})$ より小さいことが明らかと なった ${ }^{3)}$ 。従来斥力だけで説明された荷電粒子間相互作用 に対し, 長距離引力の存在 ${ }^{4)}$ が顕微鏡法や散乱法などの実 験に基づき約 20 年前より検証されてきたが，2D-USAXS の結果はその決定的な根拠のひとつとなった。また，粒子 間距離に関する同様の結果が直径 9 14 nm のデンドリ マーについてあ SAXS 法により得られ ${ }^{5}$ ，荷電粒子系にお ける引力の作用が両 $\mathrm{X}$ 線法を併用することにより系統的
に示された。

以上は，規則的に配列した構造を対象にした例であり， 相対的な散乱強度のみから構造周期が決定できた。しか し, 装置を精密に較正すれば絶対散乱強度 $\left(I_{\mathrm{abs}}\right)$ 測定む可 能となり，より定量的な情報が得られる。例えば $I_{\mathrm{abs}}$ の $q \rightarrow 0$ への外挿值から散乱体の分子量（分子集合体の場合 その会合数）などが，また， $\left(I_{\mathrm{abs}} \times q^{2}\right)$ の積分值 $(Q)$ から電 子密度ゆらぎの 2 乗平均が得られる。とくにゲルや固体中 では高分子が $10 \mathrm{~nm} \sim \mu \mathrm{m}$ オーダーにわたる凝集体や複雑 な高次構造を形成するため，構造評価には SAXS 法だけ では不十分で，超小角領域でのデータが必要不可欠であ る。筆者らは SAXS 拉よび 1D-USAXS の両方を再生セル ロースゲルに適用し， $2 \times 10^{-3} \sim 5 \mathrm{~nm}^{-1}$ にわたる広い $q$ の範用での $I_{\mathrm{abs}}$ から $Q$ を求め, ゲル中の粗密構造を評価し た6)。二相モデルを仮定し，セルロースが集積した高密度 相を球状と見なした場合の平均直径 $(d)$, 体積分率 $(\phi)$, お よび低密度相の平均セルロース濃度 $(c)$ を決定した。一例 をあげると，ゲル中では $d=12 \mathrm{~nm}, \phi=0.18$ ，および $c=$ $0.2 \mathrm{~g} / \mathrm{cm}^{3}$ であったが，ゲルを乾燥すると高密度領域がさ らに積層して $d=24 \mathrm{~nm}, \phi=0.41$ となり, セルロースの再 生過程に抢ける構造変化を明らかにした。この例からわか るように，周期構造をもたない系む含め，さまざまな高分 子系の構造に関して得られる情報量が, USAXS 抢よび SAXS の併用により飛躍的に向上する。なお, 中性子散乱 法や放射光を用いた X 線法7)では大規模な施設が必要で あるのに対し, Bonse-Hart 型 USAXS 法は研究室レベル で可能であることを付記しておく。

USAXS 装置は，いまだ十分に普及していないのが現状 であるが，高分子のさまざまな階層にわたる構造の解析手 段として，今後ますます発展するあのと期待される。

\section{文献}

1） a）松岡秀樹，伊勢典夫：高分子, 40, 462 (1991); b) H. Matsuoka, N. Ise: Adv. Polym. Sci., 114, 187 (1994)

2) T. Konishi, N. Ise: Phys. Rev. B, 57, 2655 (1998)

3) N. Ise, T. Konishi, J. Yamanaka: Current Opinion in Colloid \& Interface Science, 6, 126 (2001)

4) a) N. Ise, et al.: J. Chem. Phys., 78, 536 (1983); b) N. Ise: Angew. Chem. Int. Ed. Engl., 25, 323 (1986)

5) A. Ohshima, T. Konishi, J. Yamanaka, N. Ise: Phys. Rev. E, 64, 051808 (2001)

6) H. Ando, T. Konishi: Phys. Rev. E, 62, 727 (2000)

7) W. L. Vos, M. Megens, C. M. van Kats P. Bösecke: Langmuir, 13, 6004 (1997)

KONISHI, Toshiki レンゴー(株)中央研究所, 博士(工学)．専門=高分子構造解析

Structure Analysis of Colloidal Systems and Polymer Gels by Small-Angle and Ultra-Small-Angle X-Ray Scattering 